\title{
Histone H2B Type 1-M
}

National Cancer Institute

\section{Source}

National Cancer Institute. Histone H2B Type 1-M. NCI Thesaurus. Code C162955.

Histone H2B type 1-M (126 aa, 14 kDa) is encoded by the human H2BC14 gene. This protein plays a role in DNA accessibility. 